\title{
Tinjauan Tentang Skenario Pembelajaran Tahun Pelajaran 2020/2021 Di Kabupaten Lombok Timur
}

\author{
Sa'adah \\ Dinas Dikbud Kabupaten Lombok Timur \\ Jalan Prof. Moh. Yamin, SH, No 65 Selong \\ Email: miaki.saadah@gmail.com
}

\begin{abstract}
Abstrak: Implemenasi pembelajaran jarak jauh, untuk mendukung kebijakan belajar dari rumah (BDR) di masa darurat penyebaran Covid-19 telah memunculkan aneka temuan yang layak untuk dikaji dan didiskusikan. Dengan segala keterbatasan dan ketidaksiapan, 88,90\% respoden menyatakan bahwa kebijakan belajar dari rumah di Kabupaten Lombok Timur telah dilaksanakan dengan berbagai trik dan takik. Moda yang digunakan pun beragam, ada dalam jaringan (daring), luar jaringan (luring) serta kobinasi daring dan luring. Tulisan ini bertujuan untuk mendeskripsikan serba-serbi temuan saat pelaksanaan kebijakan BDR, yang selanjutnya diharapkan menjadi umpan balik dalam mengantisipasi kebijakan pembelajaran (jarak jauh) di masa yang akan datang. Tulisan ini dilengkapi pula dengan kajian literatur dan sejumlah kebijakan pendidikan di masa darurat Covid19, baik yang dikeluarkan oleh pemerinatah pusat maupun daerah. Dengan demikian diharapkan akan diperoleh gambaran yang lebih komprehensif dalam penentuan kebijakan dan skenario pembelajaran di tahun pelajaran 2020/2021.
\end{abstract}

Kata kunci: Belajar Dari Rumah, Umpan Balik, Skenario Pembelajaran

\section{PENDAHULUAN}

Sangat Beragam! Itulah kesan yang diperoleh dari hasil monitoring pelaksanaan pembelajaran jarak jauh, dalam rangka mendukung kebijakan belajar dari rumah (BDR) yang telah berlangsung sejak bulan Maret hingga Juni 2020. Meskipun sekolah tidak pernah memrogramkan, guru-guru tidak paham atau tidak siap dengan pembelajaran jarak jauh karena memang tidak terbiasa bahkan tidak pernah melaksanakannya, namun berbagai innovasi dan kreativitas muncul dari guru-guru yang memiliki komitmen untuk membelajarkan siswa di masa darurat Covid19. Pemanfaatan whatsAp, google form, google classroom, tranmisi radio, penyampaian materi melalui TV kabel, sampai berkeliling menjelaskan tugas/materi ke rumah-rumah siswa, membuktikan betapa beragamnya upaya yang dicobaterapkan oleh guru. Sangat disadari bahwa tidak semua upaya yang dilakukan akan sukses, namun hal tersebut penting dan harus didorong sehingga bisa ditemukan sesuatu yang bernilai bagi sekolah dan para siswa.
Kendala yang dihadapi juga beragam. Bingung tidak tahu apa yang harus dilakukan atau dalam bahasa sasak "kemomotan" karena guru-siswa belum terbiasa melaksanakan pembelajaran jarak jauh, rendahnya kemampuan teknologi, kekurangan kuota internet, dibutuhkannya waktu yang cukup lama unuk keliling kampung berkoordinasi dengan siswa dan orang tua siswa, banyak siswa harus bergiliran memakai handphone dengan orang tuanya, bahkan sering tidak bertemu dengan siswa di rumahnya. Kendala ini wajar adanya, karena sekolah memang tidak punya persiapan ditambah lagi di hari pertama penerapan kebijakan BDR sudah banyak siswa yang tidak ke sekokah, seolaholah sudah mengetahui kalau sekolah "diliburkan" sementara guru belum memberikan penjelasan apapun. Padahal menurut Simonson dkk (2015: 31), "komunitas belajar yang terdiri atas siswa, guru, dan sumber belajar", harus benar-benar dipersiapkan sebelum pembelajaran jarak jauh dilaksanakan. Selain itu Ali Taufik (2019) juga menemukan pentingnya "regulasi" dalam menetapkan batasan, capaian dan kurikulum, 
untuk opimalnya proses pembelajaran jarak jauh. Dari sisi capaian atau hasil pembelajaran misalnya, guru juga harus benar-benar memperhatikan sejumlah kriteria seperti: kejelasan dan ketepatan, berorientasi ke siswa, dapat diamati atau diukur, realistis dan dapat dicapai.

Sangat diakui bahwa proses pembelajaran jarak jauh untuk mendukung kebijakan belajar dari rumah, terlebih harus menggunakan teknologi mungkin tidak mudah terutama bagi sebagian guru. Selain dipengaruhi olah pemahaman dan keterampilan (khususnya teknologi), regulasi serta sarana-prasarana yang kurang memadai, belum optimalnya dukungan dan moivasi terutama dari pengawas sekolah (dinas pendidikan), kepala sekolah, dan orang tua siswa turut dianggap sebagai hal yang masih harus ditingkatkan. Guru-guru umumnya mengaku kesulitan untuk menemukan caracara pembelajaran yang benar-benar tepat sehingga hasilnya kurang optimal, namun yang perlu diapresiasi adalah masih ada upaya pembelajaran yang bisa dirasakan oleh siswa maupun orang tua siswa. Diyakini bahwa sekecil apapun upaya yang telah dilakukan, akan menjadi umpan balik berharga bagi peningkatan kualitas pendidikan di masa datang. Peranyaannya adalah: Apa dan bagaimana skenario pembelajaran yang mesti dipersiapkan di tahun pelajaran 2020/2021 di tengah Covid-19 masih mengintai kenyamanan masyarakat? Tulisan singkat ini dihapakan bisa berkonribusi dalam mengembangkan skenario pembelajaran di tahun Covid-19/ tahun pelajaran 2020/2021.

\section{KAJIAN PUSTAKA}

\section{Issue Seputar Covid-19 Dan Pembelajaran}

Covid-19!!! Yaaa... Corona Virus

Disease 2019 (Covid-19) telah mengejutkan negara-negara di dunia termasuk Indonesia. Bagaimana tidak, peyakit yang awalnya berkembang di Wuhan ini memiliki penularan yang sangat cepat dan masssif, sehingga World Health Organization (WHO) secara resmi menyatakannya sebagai pandemi pada Rabu, $11 \quad$ Maret $2020 \quad$ (dalam www.cnbcindonesia.com, 12 Maret
2020). Disinyalir dari www.liputan6.com (tanggal 08 April 2020), Covid-19 menjadi penyebab utama kematian di sejumlah negara di dunia seperti Italia, Spanyol, Amerika, Prancis. Korban meninggal pun tidak hanya dari kalangan masyarakat secara umum, namun tenaga medis yang notabene ketat dengan protokol kesehatan juga bisa terpapar bahkan sampai meninggal.

Di dalam negeri, dampak penyebaran Covid-19 begitu terasa baik di bidang sosial, ekonomi, pendidikan, budaya termasuk tradisitradisi keagamaan yang begitu kental dengan kehidupan sehari-hari bangsa Indonesia. Keluarnya himbauan social distancing, physical distancing, Work From Home, penutupan sementara rumah-rumah ibadah, tidak dipungkiri telah mengubah pola sikap dan perilaku masyarakat dan seringkali memunculkan suasana tidak nyaman. Salain itu banyaknya info yang berseliweran di media sosial, telah cukup membuat suasana panik bahkan menimbulkan benturan satu sama lain.

Di bidang pendidikan, dampak yang paling terasa adalah "diliburkannya" sekolah sebagai tempat berlangsungnya proses pembelajaran, sehingga kegiatan pembelajaran yang seharusnya dilakukan di sekolah dengan terpaksa harus dialihkan ke rumah-rumah. Kondisi ini memaksa semua pihak (Kepala sekolah, guru-guru, siswa, orang tua siswa, bahkan pengawas sekolah) untuk keluar dari zona nyaman dan selanjutnya mau tidak mau harus beradaptasi dan berinovasi menciptakan cara kerja yang baru. Kepala sekolah dan guru-guru harus mengubah pola pertemuaan dan pembelajaran dengan seluruh siswanya, para siswa harus belajar mandiri di rumah, orang tua siswa harus rela meluangkan banyak waktu untuk mendampingi anak-anak mereka belajar di rumah, dan Pengawas sekolah pun harus mengubah pola supevisinya.

\section{Pembelajaran Jarak Jauh Di Masa Darurat Covid-19}

Pemerintah melalui Kementerian Pendidikan dan Kebudayaan (Kemendikbud) telah melakukan berbagai penyesuaian pembelajaran dalam rangka memutus rantai penyebaran Covid-19. Penyesuaian tersebut 
tertuang dalam Surat Edaran Nomor 2 Tahun 2020 tentang Pencegahan dan Penanganan Covid-19 di lingkungan Kemendikbud serta Surat Edaran Nomor 3 Tahun 2020 tentang Pencegahan Covid-19 pada Satuan Pendidikan. "Kami mendorong para guru untuk tidak menyelesaikan semua materi dalam kurikulum. Yang paling penting adalah siswa masih terlibat dalam pembelajaran yang relevan seperti keterampilan hidup, kesehatan, dan empati," demikian disampaikan Menteri Pendidikan dan Kebudayaan (Mendikbud), Nadiem Anwar Makarim, pada acara media briefing Adaptasi Sistem Pendidikan selama Covid-19, di Istana Kepresidenan (Kamis, 14/5/2020), dilansir dari Compas.com, 15/5/2020. Tidak hanya itu, sejumlah kebijakan pun dikeluarkan untuk menyikapi perkembangan penyebaran Covid-19, seperti pembatalan ujian nasional, penyesuaian ujian sekolah, pelaksanaan pembelajaran jarak jauh, serta pendekatan online untuk proses pendaftaran siswa baru (Surat Edaran Nomor 4 Tahun 2020 tentang Pelaksanaan Kebijakan Pendidikan dalam Masa Darurat Penyebaran Covid-19), yang kemudian diperkuat dengan Surat Edaran Nomor 15 Tahun 2020 tentang Pedoman Penyelenggaraan Belajar dari Rumah dalam Masa Darurat Penyebaran Corona Virus Disease (Covid-19).

Salah satu implikasi dari kebijakan di atas adalah hadirnya pembelajaran jarak jauh untuk mendukung kebijakan belajar dari rumah (BDR). Pembelajaran jarak jauh sebagaimana disarikan dari Margaret Crockett dan Janet Foster (2005) adalah pembimbingan yang diberikan kepada siswa dengan tidak berkumpul bersama di satu tempat secara rutin untuk menerima pelajaran secara langsung dari guru. Bahan-bahan dan instruksi-instruksi detail yang bersifat khusus disediakan atau dikirimkan kepada para siswa dan selanjutnya melaksanakan tugas-tugas yang akan dievaluasi oleh guru. Menurut Simonson dkk (2015: 31) terdapat 4 (empat) karakter utama dalam pendidikan (pembelajaran) jarak jauh, yaitu: 1) didefinisikan melalui lembaga institusi, karena bukan semacam belajar mandiri atau sebuah lingkungan belajar non- akademik; 2) tejadi pemisahan ruang dan waktu antara siswa dan guru, sehingga desain program harus di rancang secara cermat untuk menjembatani perbedaan siswa dalam hal kecerdasan, budaya serta sosial; 3) terbangun komunikasi yang interaktif (meski tidak terus menerus) yang menghubungkan kelompok belajar dengan guru dan/atau sumber lain, seperti e-mail, cell phone; 4) komunitas belajar yang terdiri atas siswa, guru, dan sumber belajar seperti buku-buku, audio, vidio dan grafik yang di persiapkan dalam mengakses isi materi yang diinstruksikan. Semera Ali Taufik (2019) melihat tingkat efektifitas dan efesiensitas penerapan pembelajaran jararak jauh setidaknya dari dua hal yiatu: 1) regulasi untuk menetapkan batasan, capaian dan kurikulum yang baku untuk membentuk proses pelaksanaan kegiatan pembelajaran jarak jauh dapat dilaksanakan secara menyeluruh; dan 2) persiapan pendidik dan tenaga kependidikan yang dapat melaksanakan pembelajaran jarak jauh dengan pengembangan kompetensi teknologi dan komunikasi elektronik.

Pembelajaran jarak jauh dalam konteks BDR, secara umum didasarkan karena guru dan siswa harus terpisah dalam ruang dan waktu, komunikasi antara guru dan siswa tidak berlangsung secara terus-menerus, pengorganisasian pembelajaran dilakukan melalui berbagai media, supervisi dan pemantuan oleh pengawas sekolah menggunakan aplikasi meskipun belum maksimal. Meski dengan fokus yang berbeda, namun dari pendapat ahli di atas dapat disimpulkan bahwa pembelajaran jarak jauh pada intinya harus benar-benar dipersipakan baik dalam hal regulasi, desain program maupun sarana-prasarana. Hal ini penting karena, di satu sisi akan terjadi pemisahan ruang dan waktu antara guru dan siswa, sementara di sisi lain harus terbangun komunikasi yang interaktif antara keduanya (guru-siswa) dan sumber belajar. Selain regulasi (menetapkan batasan, hasil yang dicapai, kurikulum), desain program (untuk kegiatan daring/luring/kombinasi daringluring), dan sarana-prasarana (lembar kerja siswa, paket internet), dibutuhkan pula komitmen, kesabaran, pemahaman serta 
keterampilan yang memadai khusunya di bidang teknologi, agar pelaksanaan pembelajaran jarak jauh bisa mencapai hasil yang diharapkan.

\section{Monitoring Belajar Dari Rumah (BDR)}

Sejalan dengan kebijakan Pemerintah terkait pelaksanaan pendidikan di masa darurat Covid-19, Dinas Pendidikan dan Kebudayaan Kabupaten Lombok Timur setidaknya telah mengeluarkan empat kebijakan belajar dari rumah (BDR), 1) Surat Edaran Nomor Kepala Dinas 800/956/Dikbud.I/2020 tanggal 16 Maret 2020 yang berisikan bahwa kegiatan pembelajaran di sekolah "diliburkan" sejak tanggal 16 s.d 28 Maret 2020; 2) Edaran Nomor 800/956/Dikbud.I/2020, BDR diperpanjang dari tanggal 30 Maret s.d 13 April 2020; 3) Edaran Nomor 800/962/Dikbud.I/2020, BDR diperpanjang 13 s.d 25 April 2020; dan 4) Edaran Nomor 800/972/Dikbud.I/2020, BDR diperpanjang 27 April s.d 19 Juni 2020. Untuk mengetahui kerlaksanaan BDR termasuk Ujian Sekolah dari Rumah, pada bulan April hingga Mei 2020 telah dilakukan monitoring menggunakan aplikasi google form.

Sangat disadari bahwa, hasil monitoring ini tentu tidak dapat merepresentasikan gambaran penerapan kebijakan BDR di Lombok Timur secara proporsional, karena yang mengisi instrumen hanya mencapai 458 orang dari 1000 responden yang ditargetkan. Namun demikian, diyakini bahwa sesedikit apapun informasi terkait pengelolaan pendidikan dan pembelajaran di masa darurat penyebaran Covid-19 ini menarik untuk dikaji dan hasilnya disebarluaskan dengan harapan dapat dijadikan umpan balik bagi peningkatan kulaitas pembelajaran (jarak jauh mupun reguler) di segala situasi.

Dari hasil monitoring terungkap bahwa, meskipun persiapan dan kemampuan mengelola pembelajaran jarak jauh untuk mendukung kebijakan BDR kurang maksimal, siswa meliburkan diri sebelum guru memberikan penjelasan, tidak ada sarana yang memadai dan sebagainya, namun $88,90 \%$ responden menyatakan bahwa kebijakan BDR di Lombok Timur telah dilaksanakan dengan berbagai trik dan taktik, serta moda yang digunakan seperti dalam jaringan (daring), luar jaringan (luring) maupun kombinasi daring dan luring. Strategi yang digunakan guru untuk menjelaskan materi kepada siswa juga bervariasi, tanpa tatap muka melalui WA $(70.3 \%)$, tatap muka melelui vedio call (16.2\%), penugasan jarak jauh, dan sebagainya. Demikian juga dengan sumber belajar yang dianjurkan guru saat pelaksanaan BDR, penggunaan buku paket yang mencapai $83.8 \%$, prinout materi, transmisi radio, TVRI, dan sedikit sekali yang menggunakan aplikasi.

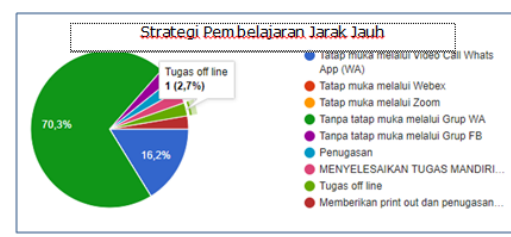

Kendala yang dihadapi juga beragam, belum terbiasanya guru melaksanakan pembelajaran jarak jauh, rendahnya kemampuan teknologi, kekurangan kuota internet, dibutuhkannya waktu yang cukup lama karena guru harus keliling kampung berkoordinasi dengan siswa dan orang tua siswa, banyak siswa harus bergiliran memakai handphone dengan orang tuanya, sering tidak bertemu dengan siswa di rumahnya, tidak maksimalnya pendampingan dari dinas terkait, dan masih banyak lagi kendala lainnya. Namun apresiasi yang tinggi disampaikan kepada rekan-rekan guru yang melakukan berbagai upaya untuk mengatasi kendala yang dihadapi, seperti keliling ke rumah-rumah siswa untuk memberikan arahan, meminta siswa belajar kelompok di Musalla bersama teman di sekitar untuk belajar dan menggunakan HP bersama, meminta bantuan kepala desa atau kadus untuk mengumumkan pentingnya BDR melalui masjid, menitipkan tugas ke orang tua siswa karena tidak menemukan siswa di rumah. Saran dari guru juga be ragam mulai dari gratiskan kuota untuk siswa dan guru, berikan pendidikan dan pelatihan teknologi bagi guru yang membutuhkan, panduan belajar jarak jauh harus dipersiapkan, perlu adanya upaya nyata untuk membangun 
persepsi yang sama dengan orang tua siswa mengenai pentingnya keterlibatan orang tua dalam menyukseskan pendidikan petra/putri mereka, termasuk meminta Dinas melakukan monitoring dan pembinaan secara intensif.

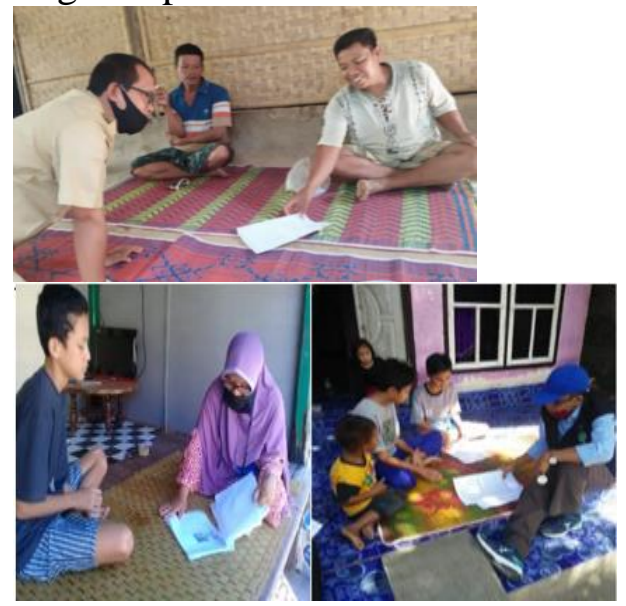

Ternyata benar adanya bahwa proses pembelajaran (jarak jauh) terlebih harus menggunakan teknologi adalah tidak mudak terutama bagi sebagian guru sehingga hasilnya kurang optimal, namun paling tidak guru-guru telah berupaya agar pembelajaran bisa terlaksana. Berikut curahan hati rekan-rekan guru yang dikutip dari WA/FB:

"saya terus mengajak teman-teman (melakukan pendampingan BDR) supaya ada proses pembelajaran yang bisa dirasakan orang tua dan siswa. Terlihat di wajah orang tua siswa, mereka sangat senang melihat langsung anak mereka dibimbing oleh gururnya."

"Gagal menggunakan aplikasi karena keterbatasan Kuota".

"Kami yang berada di wilayah timur (pulau lombok) melakukan pendampingan BDR dengan berbagai cara: pemanfaatan group WA, goole form, transmisi radio, penyampain matei melalui TV kabel, dan ternyata benar terdapat aneka jenis temuan."

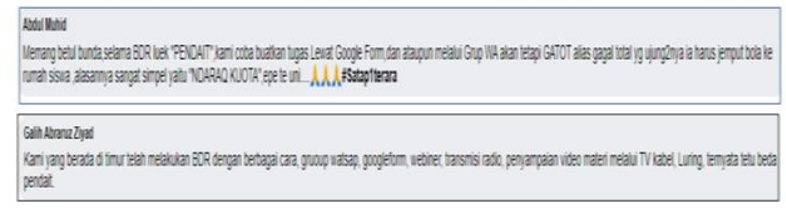

\section{METODE PENELITIAN}

Metode yang digunakan adalah analisis data hasil monitoring pelaksanaan belajar dari rumah (BDR), kajian literatur dan kebijakan, baik yang dikeluarkan pemerintah pusat maupun daerah. Analisis hasil monitoring BDR difokuskan pada keterlaksanaan, strtaegi dan media yang digunakan, kendala yang dihadapi serta solusi pemecahan masalah. Pengumpulan data dilakukan dengan memanfaatkan google form dan melibatkan 458 responden yang terdiri atas: 86 orang responden Kepala Sekolah, 244 guru, dan 128 orang tua siswa. Semua temuan, kemudian diakomodasikan dengan teori pembelajaran jarak jauh serta kebijakan yang dikeluarkan pemerintah pusat maupun daerah, dan hasil analisis nya disajikan secara deskriptif.

doang disını juga tg sama saja batur tetap tiang betejak walau pokok sak arak
juluk gerakannya yg penting ada proses di depan anak didik dan ortu wali.
ortuvwali..niki pedas ruen demen tedatenging anak jari niki te ajah le julun nie
pede. saksiang langsung anak ne teajah si gurune.

\section{HASIL DAN PEMBAHASAN}

Dengan segala keterbatasan, jiwa-jiwa inovatif bergerak, tidak bisa daring, luring pun dijalani. Orang tua siswa juga tidak mau ketinggalan, mereka ikut membaca tugas-tugas yang diberikan kepada putra-putrinya. Benar kata orang, di balik musibah pasti ada hikmah dan pelajaran. Di balik Covid-19, banyak orang terutama guru-siswa, (termasuk pengawas sekolah), berupaya menguasai teknologi yang memang sangat dibutuhkan di era 4.0 saat ini. Penggunaan media pembelajaran jarak jauh seperti whatsApp, google form, google classroom, aplikasi zoom, youtube, office 365, ramai diperbincangkan sehingga langsung-tidak langsung akan mampu meningkatkan kemampuan guru-siswa dalam menggunakan dan mengakses teknologi.

Pertanyaan adalah, apa dan bagaimana skenario pembelajaran yang harus dilpersiapkan untuk menyambut tahun pelajaran 2020/2021 di tengah issue Covid-19 yang masih menghantui seluruh lapisan masyarakat ini? Untuk menjawab pertanyaan ini, paling tidak harus dicermati dua hal berikut:

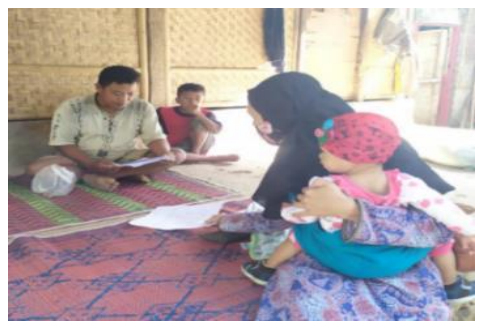


1) Paparan Mendikbud terkait Panduan Penyelenggaran Pembelajaran Tahun Ajaran Baru di Masa Pandemi Covid-19, yang disaksikan secara live melalui https://www.youtube.com/watch?v=Jt-

JRcTKHvo\&fbclid=IwAR3B-

WihCCrXaRpg8B_2nugucfkq-qJFEr-

tQA4x_6Su7aJ65h_PpQc9ikY pada tanggal 15 Juni 2020 pukul 16.30 WIB, yang melibatkan Kementerian Koordinator Pembangunan Manusia dan Kebudayaan Republik Indonesia; Badan Nasional Penanggulangan Bencana Kepala Pelaksana Gugus Tugas; Kementerian Kesehatan RI Kabinet Indonesia Maju 2019-2024; Kementerian Agama Republik Indonesia; Kementerian Pendidikan dan Kebudayaan Republik Indonesia; Kementerian Dalam Negeri Republik Indonesia; dan Komisi X DPR RI;

2) Data yang rilis pada hari Kamis, 18 Juni $2020 \quad 19: 55 \quad$ melalui https://mataram.antaranews.com/berita/123 416/mulai-hari-ini-enam-kecamatan-dilombok-timur-jadi-zona-hijau-covid-19, yang menyatakan bahwa enam kecamatan di Kabupaten Lombok Timur Nusa Tenggara Barat, sejak Kamis, 18 Juli 2020 menjadi zona hijau COVID-19, yaitu kecamatan Sakra Barat, Sakra Timur, Sambalia, Keruak, Montong Gading dan Sukamulia. Sementara itu, kecamatan yang masih zona kuning adalah Suela, Masbagik, Sembalun, wanasaba, Jerowaru dan Lenek. Sedangan kecamatan yang masih berada di zona merah yaitu Selong, Sakra, Terara, Sikur, Labuhan Haji, Pringgabaya, Wanasaba, Pringgasela dan Suralaga.

Berikut disampaikan sejumlah poin penting dari paparan Mendikbud, Mas Nadiem Makarim terkait Panduan Penyelenggaran Pembelajaran Tahun Ajaran Baru di Masa Pandemi Covid-19, yang dapat dijadikan acuan skenario pembelajaran di Kabupaten Lombk Timur pada Tahun Pelajaran baru 2020/2021.

1) "Kesehatan dan keselamatan peserta didik, pendidik, tenaga kependidikan, keluarga, dan masyarakat merupakan prioritas utama dalam menetapkan kebijakan pembelajaran" merupakan Prinsip Kebijakan Pendidikan di Masa Pandemi Covid-19.

2) Pola pembelajaran di di Masa Pandemi Covid-19, yaitu: Untuk daerah yang berada di zona kuning, oranye dan merah, dilarang melakukan pembelajaran tatap muka di satuan pendidikan. Satuan pendidikan di zona-zona tersbut tetap melanjutkan Belajar dari Rumah (BDR).

3) Ketentuan pembelajaran tatap muka di wilayah zona hijau, antara lain: harus diizinkan oleh Pemda/Kemenag, satuan pendidikan penuhi semua daftar periksa; orang tuan siswa setuju dengan pembelajaran tatap muka. Uraian lengkapnya silakan dicermati dalam paparan lengkap Menteri Pendidikan dan Kebudayaan Republik Indonesia laman Kemendikbud atau di https://www.youtube.com/watch?v=I3F6u zgqwWw.

Memperhatikan dua intrumen di atas (panduan pembelajaran dan kondisi Lombok Timur yang masih berada di sona merah, kuning, hijau), yang kemudian diakomodasikan dengan hasil monitoring Belajar dari Rumah (BDR), maka terdapat dua skenario pembelajaran yang layak dipertimbangkan untuk diterapkan di Kabupaten Lombok Timur pada tahun ajaran baru 2020/2021:

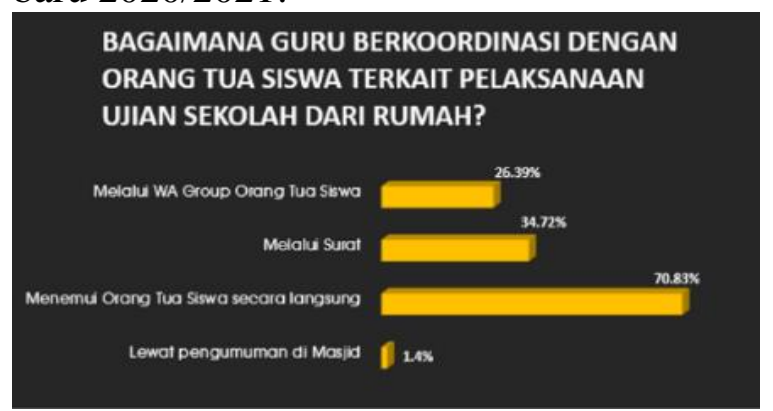

Pertama: Pembelajaran jarak jauh dalam jaringan (daring), luar jaringan (luing), atau kombinasi keduanya daring dan luring. Berdasarkan hasil monitoring yang dilakukan pada bulan April hingga Mei 2020, jumlah yang siswa memiliki gawai atau hp yang bisa digunakan untuk pembelajaran online mencapai $56.56 \%$. Data ini pun diambil pada 
sekolah pedesaan dengan kemampuan ekonomi relatif menengah ke bawah, sehingga diiyakini anak-anak yang sekolah di kota (kecamatan dan kabupaten) akan lebih banyak lagi yang memiliki sarana belajar online. Sementara itu, melihat cara guru berkomunikasi dengan orang tua siswa saat pelaksanaan ujian sekolah dari rumah mencapai lebih dari $26 \%$ memanfaatkan group WA, dan sudah ada sejumlah guru maupun pengawas yang menfaatkan aplikasi pembelajaran, maka pembelajaran jarak jauh (moda daring mupun luring), layak dan harus dikembangkan terutama di wilayah zona merah dan kuning.

Mengacu kepada sejumlah teori dan kebijakan, serta hasil monitoring pelaksanaan pembelajaran jarak jauh yang berlangsung selama hampir empat bulan (Maret hingga Juni 2020), maka kegiatan yang perlu dilakukan oleh sekolah yang akan menyelenggarakan pembelajaran jarak jauh adalah:

1) Membangun persepsi dan pemahaman yang sama antara seluruh komponen sekolah terkait makna pembelajarran jarak jauh dan hubungannya dengan kebijakan BDR, karena ini bukan semacam belajar mandiri tanpa tuntutan capaian akademik semata.

2) Mendata jumlah siswa yang memiliki gawai/laptop/pc dan sejenisnya yang dapat mendukung pembelajaran jarak jauh daring/luring/keduanya.

3) Mendata jumlah siswa yang memiliki gawai/laptop/pc yang berasal dari keluarga kurang mampu, untuk kemudian dapat dipertimbangkan diberikan bantuan paket data dari dana BOS, sebagaimana diatur dalam Peraturan Menteri Pendidikan dan Kebudayaan Republik Indonesia Nomor 19 Tahun 2020 tentang Perubahan Atas Peraturan Menteri Pendidikan dan Kebudayaan Nomor 8 Tahun 2020 tentang Petunjuk Teknis Bantuan Operasional Sekolah Reguler.

4) Mendata jumlah dan sebaran peserta didik yang tidak memiliki akses sarana pembelajaran daring maupun luring.

5) Menyusun regulasi atau panduan yang brisikan: program, kegiatan dan anggaran untuk pelaksanann pembelajaran jarak jauh; mekanisme dan durasi waktu pelaksanaan; mekanisme pelaksanaan penilaian, protokol kesehatan yang harus dipatuhi dan sebagainya.

6) Memfasilitasi optimalitas keterlaksanaan skenario pembelajaran yang diputuskan, misalnya: mengeluarkan kebijakan pemberian paket data bagi guru dan siswa, memaksimalkan media pembelajaran daring yang dimiliki, bimbingan teknis dan pelatihan untuk guru dan tenaga kependidikan yang membutuhkan.

7) Mempersipakan scenario pemantauan dan evaluasi pelaksanaan.

Penjelasan lebih rinci mengenai Media dan Sumber Belajar Jarak Jauh daring/luring dapat dilihat pada Surat Edaran Nomor 15 Tahun 2020 tentang Pedoman Penyelenggaraan Belajar dari Rumah dalam Masa Darurat Penyebaran Corona Virus Disease (Covid-19).

Kedua: Pembelajaran tatap muka seperti biasa dengan protokol kesehatan yang memadai. Untuk satuan pendidikan atau sekolah yang berada di wilayah zona hijau, sehingga aman dan nyaman untuk dibuka kembali sebagai pusat pembelajaran, kegiatan yang perlu dilakukan adalah:

1) Melakukan koordinasi dengan Kepala Dinas Pendidikan dan Kebudayaan dan/atau Kepala UPTD, Kepala Desa, Puskesmas terdekat, Komite Sekolah, Orang Tua Siswa, serta pihak terait lainnya di sekolah.

2) Melakukan pendataan warga sekolah menderita sakit dengan berbagai keluhan, serta mengidentifikasi kondisi kesiapan dan kebutuhan belajar siwa.

3) Menyusun protokol kesehatan yang memadai dan dipampang di sejumlah tempat yang mudah dibaca dan diakses oleh seluruh warga sekolah.

4) Menyepakati dan menyosialisasikan bagaimana mengatur ruang-ruang kelas, bagaimana pola belajar mengajar serta hubungan sosial di sekolah, serta bagaimana protokol kesehatan diberlakukan di sekolah. 
5) Menyediakan sarana untuk cuci tangan menggunakan air mengalir dan sabun atau pencuci tangan berbasis alkohol di berbagai lokasi strategis di sekolah sesuai dengan jumlah yang dibutuhkan.

6) Bekerjasama dengan Puskesmas terdekat untuk melakukan skrining awal berupa pengukuran suhu tubuh terhadap semua warga sekolah dan tamu yang datang ke sekolah.

7) Pemanfaatan papan sekolah aman, poster, spanduk, buletin, mading, beaner, dan lain-lain untuk mengkampanyekan pola hidup bersih dan sehat terutama dalam rangka pencegahan penyebaran Corona Virus Disease (Covid-19).

8) Mempersipakan scenario pemantauan dan evaluasi pelaksanaan.

Berikut disajikan contoh protokol kesehatan yang dihimpun dari berbagai sumber, kiranya dapat dijadikan refrensi bagi yang membutuhkan.

1) Menyediakan sarana untuk cuci tangan menggunakan air mengalir dan sabun atau pencuci tangan berbasis alkohol di berbagai lokasi strategis di sekolah sesuai dengan jumlah yang dibutuhkan.

2) Membuat kesepakatan bersama komite sekolah terkait kesiapan melakukan pembelajaran tatap muka di satuan pendidikan. Proses pembuatan kesepakatan tetap perlu menerapkan protokol kesehatan.

3) Bekerjasama dengan Puskesmas untuk melakukan skrining awal berupa pengukuran suhu tubuh terhadap semua warga sekolah dan tamu yang datang ke skolah.

4) Menindaklanjti hasil skrining awal terhadap warga sekolah yang punya keluhan sakit, dengan merujuk yang bersangkutan ke Puskesmas terdekat untuk dilakukan pemeriksaan lebih lanjut.

5) Seluruh siswa melakukan cuci tangan menggunakan air mengalir dan sabun atau pencuci tangan berbasis alkohol sebelum memasuki kelas. dan perilaku hidup bersih sehat (PHBS) lainnya seperti: makan jajanan sehat, menggunakan jamban bersih, membuang sampah pada tempatnya.

6) Membersihkan ruangan dan lingkungan sekolah secara rutin (minimal 1 kali ...) dengan desinfektan, khususnya handel pintu, saklar lampu, komputer, meja, keyboard dan fasilitas lain yang sering terpegang oleh tangan.

7) Memantau absensi (ketidakhadiran) warga sekolah. Jika diketahui tidak hadir karena sakit dengan gejala demam/batuk/pilek/sakit

tenggorokan/sesak napas disarankan untuk segera ke fasilitas kesehatan terdekat untuk memeriksakan diri.

8) Menghimbau kepada warga sekolah yang sakit dengan gejala demam/batuk/pilek/sakit tenggorokan/sesak napas untuk mengisolasi diri dirumah dengan tidak banyak kontak dengan orang lain.

9) Memastikan makanan yang disediakan di kantin sekolah merupakan makanan yang sehat dan sudah dimasak sampai matang.

10) Warga sekolah tidak berbagi makanan, minuman, termasuk peralatan makan, minum dan alat musik tiup yang akan meningkatkan risiko terjadinya penularan penyakit.

11) Warga sekolah menghindari kontak fisik langsung (bersalaman, cium tangan, dan sebagainya).

12) Menunda kegiatan yang mengumpulkan banyak orang atau kegiatan di lingkungan luar sekolah (berkemah, studi wisata).

13) Seluruh warga sekolah dan/atau tamu yang datang ke sekolah wajib menggunakan masker dan memperhaikan social distancing \& phycial distancing

\section{KESIMPULAN}

Penyebaran Corona Virus Disease 2019 (Covid-19) masih menjadi perhatian pemerintah. Untuk dunia pendidikan, Pemerintah menekankan bahwa kesehatan dan keselamatan peserta didik, pendidik, tenaga kependidikan, keluarga, dan masyarakat merupakan prioritas utama dalam menetapkan kebijakan pembelajaran, sehingga satuan 
pendidikan yang berada di zona merah, kuning, oranye, dilarang melakukan kegiatan pembelajaran tatap muka di sekolah. Adapun sekolah-sekolah yang berada di wilayah zaona hijau, diizinkan melakukan kegiatan pembelajaran tatap muka dengan sejumlah ketentuan dan protokol kesehatan yang harus dipatuhi. Oleh karena, di Kabupaten Lombok Timur (tertanggal 18 Juni 2020) masih terdapat sejumlah sekolah yang berada di di zona merah, kuning, hijau, maka pemberlakuan pembelajaran jarak jauh untuk mendukung BDR dan pembelajaran tatap muka, menjadi dua hal yang mesti diperhatikan dan dikaji secara cermat demi kebaikan, keselamatan dan kepentingan masyarakat.

\section{Saran}

Jika diberlakukan opsi pertama yakni pembelajaran jarak jauh, maka hal penting yang perlu diingat bahwa pendekatannya berbeda dengan pembelajaran tatap muka, baik dalam hal perencanaan, metode dan pola komunikasi. Dibutuhkan motivasi diri yang kuat baik siswa maupun guru untuk memulai dan mengembangkan materi dan tugas-tugas yang memang bersifat mandiri. Lebih dari itu, guru dituntut untuk mengembangkan dan menggunakan metode dan strategi pembelajaran yang memdai dalam memberikan tugas dan dukungan kepada siswa, termasuk bagaimana memfasilitasi diskusi jarak jauh. Karena itu, disarankan kepada sekolah agar pelaksanaannya benarbenar dipersiapkan baik dalam hal regulasi, desain program maupun sarana-prasarana. Dibutuhkan komitmen, kesabaran, pemahaman serta keterampilan yang memadai khusunya di bidang teknologi, agar pelaksanaan pembelajaran jarak jauh bisa mencapai hasil yang diharapkan. Karena itu, perlu diberikan pelatihan teknologi, khususnya kepada pendidik dan tenaga kependidikan yang membutuhkan.

Jika diberlakukan opsi kedua yakni pembelajaran tatap muka, maka segala ketentuan sebagaimana diinstruksikan oleh pemerintah (Kemendikbud), serta protokol kesehatan yang disisusun bersama dengan pihak-pihak terkait (Sekolah, Puskesmas,
Komite sekolah, Orang tua siswa) harus benarbenar disosialisasikan dan dipatuhi dengan baik.

Semoga kita tetap sehat dan selalu dalam lindungan Allah SWT. Aamin...

\section{DAFTAR RUJUKAN}

Ali Taufik, (2019). Perspektif Tentang Perkembangan Sistem Pembelajaran Jarak Jauh Di Kabupaten Kutai Kartanegara Kalimantan Timur, Jurnal Pendidikan: Riset dan Konseptual Vol. 3 No. 2, April 2019.

Antara News, (Kamis, 18 Juni 2020 19:55). Mulai hari ini, enam kecamatan di Lombok Timur jadi zona hijau COVID-19

https://mataram.antaranews.com/berit a/123416/mulai-hari-ini-enamkecamatan-di-lombok-timur-jadizona-hijau-covid-19,

CNBC Indonesia (2020). WHO Nyatakan Wabah COVID-19 jadi Pandemi www.cnbcindonesia.com, 12 Maret 2020

Dinas Pendidikan dan Kebudayaan Kabupaten Lombok Timur, Surat Edaran Nomor 800/956/Dikbud.I/2020 tanggal 16 Maret 2020, terkait kegiaan belajar dari rumah (BDR) yang dimulai tanggal 16 s.d 28 Maret 2020.

Dinas Pendidikan dan Kebudayaan Kabupaen Lombok Timur, Surat Edaran Nomor 800/956/Dikbud.I/2020, terkait perpanjangan waku pelaksanaan BDR dari tanggal 30 Maret s.d 13 April 2020.

Dinas Pendidikan dan Kebudayaan Kabupaten Lombok Timur, Surat Edaran Nomor 800/962/Dikbud.I/2020, terkait perpanjangan BDR dari tanggal 13 s.d 25 April 2020.

Dinas Pendidikan dan Kebudayaan Kabupaten Lombok Timur, Surat Edaran Nomor 800/972/Dikbud.I/2020, terkait perpanjangan BDR dari tanggal 27 April s.d 19 Juni 2020.

Humas Sekretariat Kabinet Republik Indonesia (15 Mei 2020) Perubahan Kebijakan Pendidikan Selama Masa 
Pandemi

Covid-19,

https://setkab.go.id/

Kementerian Pendidikan dan Kebudayaan Republik Indonesia, Surat Edaran Nomor 15 Tahun 2020 tentang Pedoman Penyelenggaraan Belajar dari Rumah dalam Masa Darurat Penyebaran Corona Virus Disease (Covid-19).

Kementerian Pendidikan dan Kebudayaan Republik Indonesia, (2020) Panduan Penyelenggaraan Pembelajaran Tahun Ajaran Baru di Masa Pandemi Covid19, diunduh dari https://www.kemdikbud.go.id/main/bl og/2020/06/panduan-

penyelenggaraan-pembelajarantahun-ajaran-baru-di-masa-pandemicovid19.

Keputusan Bersama Menteri Pendidikan dan Kebudayaan, Menteri Agama, Menteri Kesehatan, dan Menteri dalam Negeri Republik Indonesia Nomor 01/IKB/2020; Nomor 516 Tahun 2020; Nomor HK.03.01/Menkes/363/2020; Nomor 440-842 Tahun 2020 tentang Panduan Penyelenggaraan Pembelajaran pada Tahun Ajaran 2020/2021 dan Tahun Akademik 2020/2021 di Masa Pandemi Corona Virus Disease 2019 (Covid-19)

Menteri Pendidikan dan Kebudayaan Republik Indonesia, Surat Edaran Nomor 3 Tahun 2020 tentang Pencegahan Corona Virus Disease (Covid-19) pada Satuan Pendidikan.

Menteri Pendidikan dan Kebudayaan Republik Indonesia, Surat Edaran Nomor 4 Tahun 2020 tentang Pelaksanaan Kebijakan Pendidikan dalam Masa Darurat Corona Virus Disease (Covid-19).

Menteri Pendidikan dan Kebudayaan Republik Indonesia, (15 Juni 2020 pukul 16.30 WIB) Panduan Penyelenggaran Pembelajaran Tahun Ajaran dan Tahun Akademik Baru di Masa Pandemi Covid-19, https://www.youtube.com/watch?v=Jt
-JRcTKHvo\&fbclid=IwAR3BWihCCrXaRpg8B_2nugucfkq-qJFErtQA4x_6Su7aJ65h_PpQc9ikY.

Munir. (2009). Pembelajaran Jarak Jauh Berbasis Teknologi Informasi dan Kominukasi. Alfabeta, Bandung

Nur Fitriatus Shalihah (2020). "Saat Covid-19 Jadi Penyebab Kematian Utama di AS Kalahkan

Jantung...", https://www.kompas.com/ 2020/04/12

Peraturan Menteri Pendidikan dan Kebudayaan Republik Indonesia Nomor 19 Tahun 2020 tentang Perubahan Atas Peraturan Menteri Pendidikan dan Kebudayaan Nomor 8 Tahun 2020 tentang Petunjuk Teknis Bantuan Operasional Sekolah Reguler.

Simonson, M. (2015). Teaching and Learning at a distanc, https://drive.google.com/file/d/lqjXFK $x z u R Q R T 2 L V n h R U s K m K E W v W f D J f / v i$ ew? usp=sharing 